Website: https://hipotenusa.iainsalatiga.ac.id/index.php/hipotenusa/index

M. Farid Nasrulloh, Siti Hanik, Wisnu Siwi Satiti

\title{
E-Comic Learning Media Based Problem Based Learning In Subject of Linear Equation System
}

\author{
*M. Farid Nasrulloh ${ }^{1}$, Siti Hanik ${ }^{2}$, Wisnu Siwi Satiti ${ }^{3}$ \\ 1,2,3 Program Studi Pendidikan Matematika Universitas KH. A. Wahab Hasbullah, Indonesia. \\ Email: faridnasrulloh@unwaha.ac.id ${ }^{1}$, sitihanik59@gmail.com², siwi.wisnu@gmail.com ${ }^{3}$ \\ *Correspoding Author \\ DOI: https://doi.org/10.18326/hipotenusa.v2i1.34-40
}

Submission Track:

Received : :16-06-2020

Final Revision : 25-06-2020

Available onlie : $30-06-2020$

\begin{abstract}
Abstrak
Penelitian ini bertujuan untuk mengetahui kelayakan dari media pembelajaran $e$-comic berbasis $\mathrm{PBL}$ (Problem Based Learning). Penelitian ini merupakan jenis penelitian dan pengembangan atau Research and Development $(R \& D)$. Model pengembangan yang digunakan adalah model pengembangan ADDIE dengan tahapan: analisis (Analysis), desain (Design), pengembangan (Development), implementasi (Implementation), dan evaluasi (Evaluation). Subyek penelitian ini adalah peserta didik kelas VII D MTsN 12 Jombang. Instrumen penelitian yang digunakan dalam pengumpulan data adalah (1) lembar angket dan (2) hasil respon peserta didik. Hasil penelitian menunjukkan bahwa kevalidan media pembelajaran diperoleh berdasarkan penilaian dari validasi ahli materi (dosen pendidikan matematika) terdapat 4,2 dengan kategori valid, penilaian dari validasi ahli materi (guru mata pelajaran matematika) terdapat 4,8 dengan kategori sangat valid, sedangkan validasi ahli media terdapat 4,53 dengan kategori sangat valid dan respon peserta didik terdapat $94 \%$ dengan kategori sangat setuju.
\end{abstract}

Kata Kunci : E-Comic. PBL (Problem Based Learning)

\begin{abstract}
This study aims to learn the feasibility of e-comic media in MTsN 12 Jombang. The method of this research is Research and Development $(R \& D)$. The development model used is the ADDIE development model with stages: analysis (analysis), design (design), development (development), implementation (implementation), and evaluation (evaluation). The subjects of this research were students of class VII D of MTsN 12 Jombang. The research instruments used in data collection were (1) questionnaire sheets and (2) students' response results. The results showed that the validity of the learning media obtained was based on the validation of the material experts showed 4.2 with a valid category, assessment of the validation of the material experts showed 4.8 with a very valid category, validation of the existing media experts showed 4.53 with a very valid category and participant responses students there are $94 \%$ with the category of strongly agree.
\end{abstract}

Keywords: E-Comic. PBL (Problem Based Learning) 


\section{PENDAHULUAN}

Permendiknas Nomor 20 Tahun 2003 tentang Sistem Pendidikan Nasional menyatakan bahwa pendidikan adalah usaha sadar dan terencana untuk mewujudkan suasana belajar dan proses pembelajaran agar peserta didik secara aktif mengembangkan potensi dirinya untuk memiliki kekuatan spiritual keagamaan, pengendalian diri, kepribadian, kecerdasan, akhlak mulia, serta keterampilan yang diperlukan bagi dirinya, masyarakat, bangsa, dan negara. Permendiknas Nomor 22 Tahun 2006 menyebutkan bahwa pelajaran matematika perlu diberikan kepada semua peserta didik baik pada pendidikan dasar maupun menengah untuk membekali peserta didik dengan kemampuan berpikir logis, analitis, sistematis, kritis dan kreatif, serta kemampuan bekerja sama. Pembelajaran matematika di sekolah diarahkan pada pencapaian standar kompetensi dasar oleh peserta didik. Sehingga, kegiatan pembelajaran matematika tidak berorientasi pada penguasaan materi semata, tetapi materi pada matematika merupakan alat dan sarana untuk mencapai standar kompetensi.

Matematika adalah ilmu yang memiliki sifat khas yaitu objek bersifat abstrak, menggunakan lambang-lambang yang tidak banyak digunakan dalam kehidupan seharihari, dan proses berpikir yang dibatasi oleh sturan-aturan yang ketat (Supatmono, 2002). Matematika merupakan suatu bahan kajian yang memiliki objek abstrak dan dibangun melalui proses penalaran dedukatif yaitu kebenaran suatu konsep diperoleh sebagai akibat logis dari kebenaran sebelumnya sudah diterima sehingga keterkaitan antara konsep dalam matematika bersifat sangat kuat dan jelas.

Teori perkembangan kognitif yang diungkapkan oleh Piaget menyebutkan bahwa anak usia 11-15 tahun (usia sekolah menengah) berada pada tahap formal operasional. Pada tahap ini peserta didik SMP memiliki kemampuan mengoordinasikan baik secara bersamaan ataupun berurutan dua macam kemampuan kognitif, yaitu kapasitas menggunakan prinsip-prinsip abstrak. Selanjutnya, dengan kapasitas menggunakan prinsip-prinsip abstrak, remaja tersebut akan mampu mempelajari materi- materi yang abstrak, seperti ilmu agama, ilmu matematika, dan ilmu-ilmu abstrak lainnya dengan luas dan lebih mendalam (Syah, 2004). Tahap perkembangan ini juga sebagai masa peralihan peserta didik dari jenjang SD ke jenjang SMP, dimana peserta didik dilatih untuk dapat belajar aktif dan mandiri.

Salah satu masalah yang dihadapi dunia pendidikan adalah lemahnya proses pembelajaran. Dalam proses pembelajaran anak kurang didorong untuk mengembangkan kemampuan berpikir kreatif. Proses pembelajaran di kelas hanya diarahkan pada kemampuan anak untuk mengahafal informasi termasuk pada materi Sistem persamaan linear (Nasrulloh, 2019).

Sistem persamaan linear merupakan bagian dari matematika yang mempelajari tentang persamaan yang memiliki variabel berpangkat satu. Materi sistem persamaan linear merupakan materi yang biasanya bisa dikaitkan dalam kehidupan sehari-hari. Meskipun demikian, masih banyak konsepkonsep yang belum dipahami oleh peserta didik. Hal ini masih sering terlihat dari hasil belajar yang belum mencapai batas tuntas yang ditentukan. Melihat kondisi tersebut guru perlu memahami dan mengembangkan strategi dalam pembelajaran matematika yang lebih komunikatif dan menarik.

Penggunaan media pembelajaran yang sesuai dengan materi merupakan sarana untuk mengefektifkan proses penyampaian materi kepada peserta didik. Pembelajaran melalui karakter e-comic dapat merangsang dan meningkatkan kemampuan komunikasi matematis peserta didik. Komik matematika sebagai media pembelajaran pendukung bahan ajar dapat mempermudah peserta didik untuk belajar, baik di dalam maupun di luar jam pelajaran (Adeliyanti dkk., 2018). Komik telah mampu meningkatkan daya tarik belajar siswa dan memiliki dampak positif terhadap pembelajaran karena komik menjadi media yang menarik (Hermawan dkk., 2018)

Penelitian pengembangan yang serupa dilakukan oleh Purbo Astuti (2015) dengan judul Efektivitas Media Komik Pada Pembelajaran Sistem Persamaan Linear Satu Variabel Ditinjau Dari Hasil Belajar, Minat, dan Perhatian Siswa Kelas VII B SMP Maria Immaculata Yogyakarta. Tujuan dari penelitian 
pengembangan ini adalah untuk mengetahui efektivitas pembelajaran dengan menggunakan media komik yang dilaksanakan dengan pendekatan saintifik ditinjau dari hasil belajar peserta didik, mengetahui minat, dan perhatian peserta didik dengan media komik pada pokok bahasan Sistem Persamaan Linear Satu Variabel (SPLSV) di kelas VII B SMP Maria Immaculata Yogyakarta tahun ajaran 2014/2015. Hasil penelitian menunjukkan bahwa Penerapan pembelajaran SPLSV dengan media komik efektif menumbuhkan minat dan perhatian peserta didik pada proses pembelajaran matematika dan Penerapan pembelajaran SPLSV dengan media komik kurang efektif untuk meningkatkan hasil belajar peserta didik yang berarti bahwa hasil penelitian disebutkan bahwa penggunaan media masih belum dapat memberikan hasil belajar yang baik untuk peserta didik kelas SMP Maria Immaculata karena situasi kelas dan kemampuan siswa yang berbeda di tiap kelasnya.

Berdasarkan wawancara peneliti dengan beberapa peserta didik kelas VII diperoleh informasi bahwa dalam mengajarkan matematika guru belum menggunakan media $e$ comic sebagai media pembelajaran pada materi Sistem Persamaan Linear. Konsep dari materi ini cukup abstrak dan membingungkan. Media $e$ comic ini dapat menjadi bahan belajar yang menarik minat belajar peserta didik serta dapat menambah efektifitas proses pembelajaran sehingga pembelajaran matematika dapat dinilai menjadi pembelajaran yang bermakna. Media e-comic ini diharapkan dapat menjadi salah satu alternatif dalam menciptakan pembelajaran yang menarik dan menyenangkan, sehingga peserta didik tidak jenuh dengan pembelajaran yang disiapkan oleh guru. Kejenuhan dapat muncul karena hasil belajar yang kurang baik dan memerlukan waktu yang cukup lama dalam melakukan proses pembelajaran tersebut. Kejenuhan juga dapat terjadi karena keletihan (indera, fisik, mental) pada peserta didik sehingga menimbulkan kebosanan. Sehingga faktor kejenuhan ini dapat mempengaruhi hasil belajar peserta didik.

\section{METODE}

Penelitian ini merupakan jenis penelitian dan pengembangan atau Research and Development (R\&D). Penelitian dan pengembangan adalah metode penelitian yang digunakan untuk menghasilkan produk tertentu dan menguji keefektifan produk tersebut (Sugiyono, 2016). Model penelitian pengembangan ini menggunakan model pengembangan ADDIE. Menurut Sugiyono (2016) model ADDIE terdiri dari lima tahap utama, yaitu: (1) Tahap analisis (Analysis), (2) Tahap desain (Detains), (3) Tahap pengembangan (Development), (4) Tahap implementasi (Implementation); (5) Tahap evaluasi (Evaluation). Peneliti memilih model pengembangan ADDIE berdasarkan atas pertimbangan bahwa model ini disusun secara sederhana dan sistematis. Sifatnya yang sederhana dan terstruktur dengan sistematis maka model desain ini mudah dipahami dan diaplikasikan sehingga model pengembangan ini dirasa akan lebih efektif, dinamis, dan mendukung penelitian pengembangan yang dilakukakan oleh peneliti. Peneliti memodifikasi model pengembangan sesuai dengan kebutuhan.

Prosedur penelitian dan pengembangan ini menjelaskan langkah- langkah yang dilakukan oleh peneliti dalam melakukan penelitian pengembangan media pembelajaran e-comic. Langkah-langkah tersebut adalah sebagai berikut:

\section{Analisis (Analysis)}

Pada tahap ini dilakukan studi literatur dalam pengumpulan informasi untuk mencari potensi masalah yang berkaitan dengan pengembangan media pembelajaran $e$ comic. Pengumpulan data dan informasi dilakukan secara observasi lapangan dengan melakukan wawancara kepada salah satu guru mata pelajaran matematika dan peserta didik MTs Negeri 12 Jombang untuk mengetahui data tentang siswa, kurikulum, model pembelajaran yang digunakan pendidik, serta permasalahan yang terjadi pada pembelajaran yang disampaikan kepada peserta didik di sekolah. Pada tahap ini juga dilakukan tahapan-tahapan analisis, seperti analisis materi, analisis tujuan pembelajaran, dan analisis kebutuhan peserta didik.

\section{Desain (Design)}

Hal yang dilakukan pada tahap desain adalah menyusun rencana dalam proses pengembangan produk. Langkah awal yaitu menetapkan materi pembahasan yang akan 
digunakan dalam pengembangan media pembelajaran e-comic. Berikut ini kegiatankegiatan yang akan dilakukan peneliti dalam tahap desain: 1) menyusun garis-garis besar pembelajaran, meliputi kompetensi inti, kompetensi dasar, indikator, tujuan pembelajaran, dan materi pembelajaran; 2) menyiapkan buku referensi, mencari atau mengumpulkan materi yang berkaitan dengan konsep dan materi pada pokok bahasan sistem persamaan linear SMP kelas VII serta menyusun soal-soal latihan yang akan dicantumkan pada media pembelajaran $e$ comic; dan 3) menyusun alur dan rencana pembelajaran guna pengaplikasian media pembelajaran e-comic pada pokok bahasan sistem persamaan linear SMP kelas VII yang akan dikembangkan.

Pengembangan (Development)

Pada tahap ini merupakan proses pembuatan atau mewujudkan dari proses desain, dimana pengembangan produk yang dibuat adalah e-comic. Media e-comic dibuat sesuai kebutuhan siswa yang berdasarkan pada data hasil observasi pada tahap analisis dan mengacu pada rencana yang disusun pada tahap desain. Hasil desain produk yang telah siap diberikan kepada para ahli, yaitu ahli desain media pembelajaran dan ahli materi pembelajaran matematika pokok bahasan sistem persamaan linear untuk dilakukan validasi.

Pada tahap ini mulai dilakukan pengembangan media pembelajaran e-comic berbasis PBL (Problem Based Learning) dengan melakukan kegiatan-kegiatan sebagai berikut: a) perancangan proses pengembangan media pembelajaran e-comic berbasis PBL (Problem Based Learning); b) melakukan konsultasi terlebih dahulu kepada dosen pembimbing untuk direvisi dan ditindaklanjuti; c) melakukan validasi media pembelajaran dengan meminta pendapat dan saran dari para ahli dan melakukan perbaikan terhadap media pembelajaran yang akan diujicobakan; d) melakukan perbaikan terhadap media pembelajaran yang telah divalidasi dan layak untuk diujicobakan baik dari segi penampilan maupun cakupan materi; dan e) pembuatan desain karakter maupun desain materi media pembelajaran e-comic dengan software corel draw. Format e-comic matematika dikembangkan dalam bentuk
Portable Document Format (PDF) dan diunggah pada laman wordpress dalam bentuk website.

\section{Implementasi (Implementation)}

Implementasi adalah langkah untuk menerapkan dan uji coba desain yang sedang kita buat. Pada tahap ini semua yang telah kita persiapkan dengan matang sesuai dengan peran dan fungsi agar mampu diimplementasikan. Uji coba dilakukan untuk mengetahui respon siswa terhadap desain yang telah dibuat.

\section{Evaluasi (Evaluation)}

Pada tahap ini dilakukan evaluasi produk berdasarkan hasil implementasi yang telah dilakukan untuk melihat kelayakan dan keefektifan media pembelajaran e-comic terhadap proses pembelajaran matematika.

Uji coba produk merupakan bagian yang sangat penting dalam penelitian dan pengambangan $(R \& D)$ untuk mengetahui tingkat kelayakan dan efektifitas produk yang telah dikembangkan. Uji coba produk merupakan tahap penting yang harus dilakukan oleh peneliti dalam penelitian pengembangan. Beberapa hal yang perlu diperhatikan dalam uji coba produk yaitu: (1) Desain Uji Coba, (2) Subjek Uji Coba, (3) Jenis Data, (4) Instrumen Pengumpulan Data, (S) Teknik Analisa Data. Telaah oleh ahli dilakukan oleh tiga subjek, yaitu ahli materi (Ibu Khusnul Khotimah, M. Pd. selaku Dosen Pendidikan Matematika), ahli materi (Bapak Agus Masyhudi, S. Pd selaku Guru Mata Pelajaran Matematika), dan ahli media pembelajaran (Bapak Moh. Anshori Aris Widya, M.Kom selaku Dosen Teknologi Informasi). Telaah oleh ahli ini dilakukan untuk mengetahui kelayakan dari media yang dikembangkan untuk selanjutnya agar dapat dilakukan uji coba terbatas.

Uji coba terbatas dilakukan pada subyek uji coba untuk melaksanakan pembelajaran menggunakan media pembelajaran yang telah dikembangkan, dalam ha1 ini adalah media pembelajaran e-comic. Subyek penelitian pada penelitian pengembangan ini adalah peserta didik kelas VII Madrasah Tsanawiyah Negeri 12 Jombang tahun ajaran 2019/2020 yang berjumlah 34 peserta didik. Analisis kevalidan diperlukan untuk mengetahui valid atau tidaknya produk yang dikembangkan jika digunakan dalam proses pembelajaran matematika, khususnya 
pada materi sistem persamaan linear SMP Kelas VII. Analisis kevalidan dilakukan dengan menggunakan instrumen validasi materi oleh ahli, instrumen validasi media oleh ahli, serta angket respon peserta didik. Data yang diperoleh dari validasi selanjutnya dianalisis secara deskriptif.

\section{HASIL DAN PEMBAHASAN}

Penelitian ini bertujuan untuk mengembangkan dan mendeskripsikan kelayakan media e-comic sebagai media alternatif pada pokok bahasan sistem persamaan linear SMP. Model pengembangan yang digunakan adalah model pengembangan ADDIE. Model ADDIE terdiri dari lima tahap yaitu analisis (analysis), desain (design), pengembangan (development), implementasi (implementation), evaluasi (evaliation).

Tahap Analisis (Analysis)

Tahap analisis materi dilakukan dengan mengumpulkan berbagai informasi mengenai materi sistem persamaan linear SMP/MTs kelas VII dari berbagai sumber, seperti buku paket siswa, lembar kerja siswa, dan sumber referensi lainnya. Berdasarkan analisis materi yang telah dilakukan, maka tujuan pembelajaran mengacu pada Kompetensi Inti dan Kompetensi Dasar yang harus dikuasai peserta didik pada materi sistem persamaan linear SMP/MTs kelas VII. Berdasarkan hasil pengamatan peneliti, diketahui bahwa peserta didik lebih berminat dan tertarik untuk mengikuti proses pembelajaran matematika dengan menggunakan media e-comic. Hal ini dikarenakan media pembelajaran e-comic belum pernah diberikan oleh pendidik selama proses pembelajaran berlangsung serta adanya animasi dan sajian materi yang tidak membosankan sehingga kefektifan pembelajaran dapat dimaksimalkan.

Tahap Desain (Design)

Tahap desain dilaksanakan berdasarkan hasil pada tahap analisis. Berdasarkan data yang diperoleh peneliti dalam tahap analisis bahwa media e-comic dapat membantu peserta didik dalam memahami konsep dan materi pada matematika, khususnya pada materi sistem persamaan liner satu variabel SMP. Pemilihan media pembelajaran yang akan dikembangkan didasarkan pada hasil analisis materi dan kebutuhan peserta didik sehingga akan didapatkan hasil media pembelajaran yang menarik, efektif terhadap proses pembelajaran serta tidak membosankan. Media pembelajaran yang hendak dikembangkan adalah media pembelajaran e-comic. Berikut ini penjelasan terperinci mengenai langkah- langkah dalam tahap desain

\section{Langkah Awal}

Langkah awal dalam tahap desain adalah tahap penyusunan materi. Dalam tahap ini dimulai dengan menggali dan mengumpulkan materi serta soal-soal latihan pada pokok bahasan sistem persamaan linear SMP Kelas VII. Pengumpulan materi bersumber dari buku paket siswa, lembar kerja siswa (LKS) serta sumber referensi lainnya. Materi yang telah terkumpul selanjutnya dirancang dan didesain dengan menggunakan Microsoft Word.

\section{Langkah Kedua}

Tahap kedua dalam pengembangan media pembelajaran e-comic adalah mengubah materi yang telah disusun dalam bentuk Microsoft Word menjadi bentuk PDF (Portable Document Format). Sebelum diubah dalam bentuk PDF, materi yang telah disusun dalam bentuk Microsoft Word didesain menggunakan Corel Draw.

Berkut ini tampilan media e-comic dalam PDF (Portable Document Format)

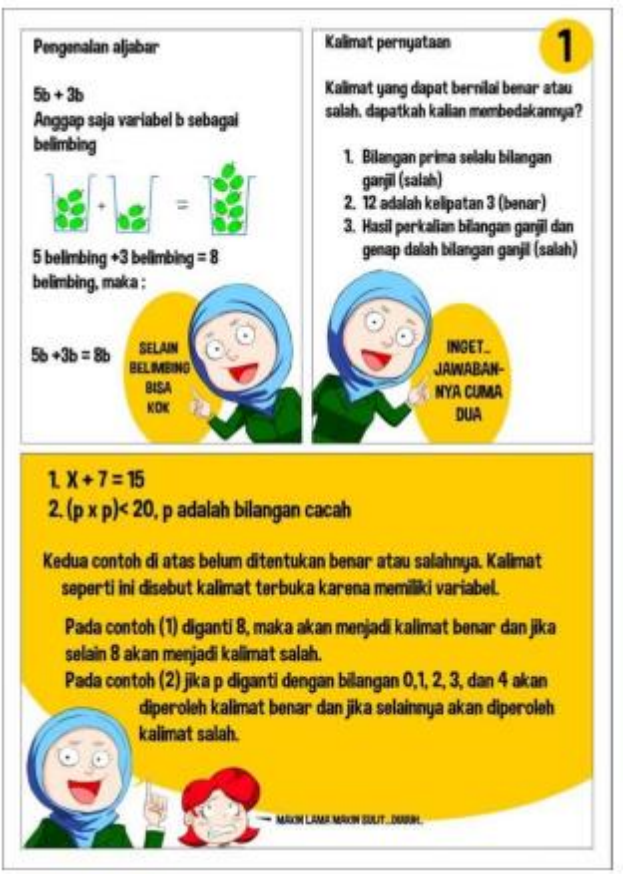

Gambar 1. Tahap dalam bentuk artikel 
Langkah Ketiga

Tahap ketiga dalam pengembangan media pembelajaran e-comic adalah mengunggah media yang telah disiapkan ke dalam akun website. Dalam penelitian pengembangan ini menggunakan akun website dari wordpress.

\section{Tahap Pengembangan (Development)}

Tahap pengembangan (development) merupakan tahap lanjutan dari tahap desain. Dalam tahap ini, media pembelajaran $e$-comic yang telah didesain sedemikian hingga telah divalidasi oleh ahli materi serta ahli media pembelajaran sehingga dapat dikembangkan kembali sesuai dengan saran dan masukan dari para validator. Saran dan masukan dari para validator selanjutnya diperhatikan oleh peneliti demi menjadikan media pembelajaran e-comic lebih baik dan lebih layak untuk digunakan dalam proses pembelajaran.

Tabel 1 Hasil Validasi Ahli Materi (Ibu Khusnul Khotimah, M.Pd. selaku Dosen Pendidikan Matematika)

\begin{tabular}{|c|c|c|c|c|c|}
\hline$\overline{\text { No }}$ & $\begin{array}{l}\text { Aspek } \\
\text { Penilaian }\end{array}$ & $\begin{array}{c}\text { No } \\
\text { Butir }\end{array}$ & $\begin{array}{c}\text { Skor } \\
\text { Ahli } \\
\text { Materi }\end{array}$ & $\begin{array}{c}\text { Jumlah } \\
\text { Skor } \\
\text { tiap } \\
\text { Aspek }\end{array}$ & $\begin{array}{l}\text { Jumlah } \\
\text { Indikator }\end{array}$ \\
\hline \multirow[t]{5}{*}{1} & Relevansi & 1 & 4 & 21 & 13 \\
\hline & & 2 & 4 & & \\
\hline & & 3 & 4 & & \\
\hline & & 4 & 5 & & \\
\hline & & 5 & 4 & & \\
\hline \multirow[t]{3}{*}{2} & Keakuratan & 1 & 4 & 11 & \\
\hline & & 2 & 3 & & \\
\hline & & 3 & 4 & & \\
\hline 3 & $\begin{array}{l}\text { Kelengkapan } \\
\text { Sajian }\end{array}$ & 1 & 4 & 4 & \\
\hline 4 & $\begin{array}{l}\text { Konsep } \\
\text { Dasar Materi }\end{array}$ & 1 & 4 & 4 & \\
\hline \multirow[t]{5}{*}{5} & $\begin{array}{l}\text { Kesesuaian } \\
\text { sajian }\end{array}$ & 1 & 5 & 14 & \\
\hline & $\begin{array}{l}\text { dengan } \\
\text { tuntutan }\end{array}$ & 2 & 5 & & \\
\hline & $\begin{array}{l}\text { pembelajaran } \\
\text { yang } \\
\text { terpusat } \\
\text { pada siswa }\end{array}$ & 3 & 4 & & \\
\hline & Jumlah Skor & & & 54 & 13 \\
\hline & Penilaian Has & sil Kel & ayakan & 4,2 & Valid \\
\hline
\end{tabular}

Tahap Implementasi (Implementation)

Pada tahap ini dilaksanakan di Madrasah Tsanawiyah Negeri 12 Jombang dengan responden peserta didik kelas VII D yang berjumlah 34 peserta didik. Penelitian dilakukan dengan menguji keefektifan media pembelajaran dengan memberikan soal pre test dan post test sebagai tolak ukurnya. Sedangkan hasil kelayakan diuji dengan melihat hasil angket respon peserta didik dan hasil validasi oleh ahli materi serta ahli media pembelajaran.

\section{Tahap Evaluasi (Evaluation)}

Tahap evaluasi dilakukan untuk mengetahui apakah media pembelajaran $e$ comic layak dan efektif ataukah tidak untuk digunakan dalam proses pembelajaran matematika, khususnya pada materi sistem persamaan linear kelas VII. Hasil evaluasi diperoleh dari angket respon peserta didik setelah diberi media pembelajaran e-comic pada proses pembelajaran materi pokok sistem persamaan linear.

Uji Validitas

Data hasil uji validasi materi dilakukan oleh dosen pendidikan matematika Universitas KH. A. Wahab Hasbullah Tambakberas Jombang. Ahli materi melakukan validasi sebanyak satu kali. Berdasarkan data yang diperoleh, maka dapat dilakukan penghitungan untuk keseluruhan Skor 54 pada penghitungan, diperoleh dari jumlah skor hasil validasi dari ahli materi. Sedangkan skor 13 diperoleh dari penghitungan banyaknya indikator penilaian. Atas dasar penilaian tersebut di atas, dapat disimpulkan bahwa total penilaian hasil validasi adalah 4,2. Berdasarkan pedoman kriteria kevalidan, maka materi yang ada pada media pembelajaran e-comic pada materi sistem persamaan linear SMP kelas VII dalam kualifikasi valid, artinya materi sudah layak untuk digunakan dalam pembelajaran matematika pokok bahasan sistem persamaan linear SMP kelas VII.

Data hasil uji validasi media dilakukan oleh dosen pendidikan matematika Universitas KH. A. Wahab Hasbullah Tambakberas Jombang. Ahli media melakukan validasi sebanyak satu kali. Berdasarkan data yang diperoleh, didapatkan Skor 68 pada penghitungan, diperoleh dari jumlah skor hasil validasi dari ahli media. Sedangkan skor 15 diperoleh dari penghitungan banyaknya indikator penilaian. Atas dasar penilaian tersebut, dapat disimpulkan bahwa total penilaian hasil validasi adalah 4,53. Berdasarkan pedoman kriteria kevalidan, maka 
media e-comic bernasis PBL (Problem Based Learning)pada materi sistem persamaan linear SMP kelas VII dalam kualifikasi sangat valid, artinya media sudah layak untuk digunakan dalam pembelajaran matematika pokok bahasan sistem persamaan linear SMP kelas VII.

Respon peserta didik diperoleh dari hasil angket yang telah diisi oleh responden setelah mengikuti uji coba pembelajaran matematika menggunakan media pembelajaran e-comic. Uji coba dilakukan pada tahap implementasi setelah mendapat nilai kevalidan dari para ahli materi dan ahli media. Uji coba pada penelitian ini dilakukan kepada 34 peserta didik kelas VII D MTs Negeri 12 Jombang. Skor 37,6 diperoleh dari hasil penjumlahan nilai keseluruhan skor tiap aspek. Sedangkan nilai 40 diperoleh dari jumlah skor maksimal. Atas dasar penilaian tersebut di atas, dapat diperoleh hasil total persentase sebanyak $94 \%$. Berdasarkan kriteria kelayakan media, maka media pembelajaran e-comic berbasis PBL (Problem Based Learning) pada pokok bahasan sistem persamaan linear SMP kelas VII dalam kualifikasi sangat setuju, artinya media pembelajaran e-comic berbasis PBL (Problem Based Learning) layak digunakan dalam proses pembelajaran matematika.

\section{SIMPULAN}

Hasil analisis data dari validasi ahli materi (dosen pendidikan matematika) terdapat 4,2 dengan kategori valid, artinya materi layak digunakan dalam proses pembelajaran matematika, khususnya pada materi sistem persamaan linear SMP Kelas VII, validasi ahli materi (guru mata pelajaran matematika di sekolah) terdapat 4,8 dengan kategori sangat valid, artinya materi sangat layak dimasukkan dalam media pembelajaran - e-comic. Sedangkan dari ahli media terdapat 4,53 dengan kategori sangat valid, artinya media sangat layak digunakan pada proses pembelajaran matematika, khususnya pada pokok bahasan sistem persamaan linear SMP Kelas VII. Hasil respon peserta didik terdapat $94 \%$ dengan kategori sangat setuju, artinya media pembelajaran $e$-comic sangat layak digunakan dalam proses pembelajaran matematika.

\section{DAFTAR PUSTAKA}

Adeliyanti, S., Hobri, H., \& Suharto, S. (2018). Pengembangan E-Comic Matematika Berbasis Teknologi Sebagai Suplemen Pembelajaran Pada Aplikasi Fungsi Kuadrat. KadikmA, 9(1), 123-130.

Hermawan, L. I., Hobri, H., Murtikusuma, R. P., Setiawani, S., \& Yudianto, E. (2018). Pengembangan E-Comic Berbantuan Pixton pada Materi Program Linear Dua Variabel. KadikmA, 9(2), 78-88.

Nasrulloh, M. F. (2019). Penerapan Pembelajaran Model Kooperatif Tipe TAI (Team Assisted Individualization) untuk Meningkatkan Kreativitas dan Prestasi Belajar Matematika Siswa Kelas X MIPA: Indonesia. Jurnal Manajemen Pendidikan Islam AlIdarah, 4(1), 7-15.

Purbo Astuti, R. (2015). Efektifitas Media Komik Pada Pembelajaran Sistem Persamaan Linear Satu Variabel Ditinjau Dari Hasil Belajar, Minat, Dan Perhatian Siswa Kelas VII B SMP Maria Immaculata Yogyakarta. Skripsi tidak diterbitkan. Fakultas Keguruan dan Ilmu Pendidikan Universitas Sanata Dharma Yogyakarta.

Sugiyono. (2016). Metode Penelitian Kuantitatif, Kualitatif, dan $R \& D$. Alfabeta.

Sugiyono. (2016). Statistika Untuk Penelitian. Alfabeta.

Supatmono, C. (2002). Matematika Asyik. Grafindo.

Syah, M. (2004). Psikologi Pendidikan Dengan Pendekatan Baru. Remaja Rosdakarya. 